\title{
Hubungan Pemberian Konseling oleh Petugas Kesehatan dengan Pemilihan Metode Kontrasepsi Jangka Panjang (MKJP) di Puskesmas Pakuan Baru
}

\author{
Ria Febrina \\ Prodi D III Kebidanan, STIKes Baiturrahim Jambi \\ Email: febrinaria2002@gmail.com.
}

Submitted : 17/12/2020

Accepted: 10/09/2021

Published: 15/09/2021

\begin{abstract}
An increase in population can lead to poverty, economic inequality in the population which is usually measured by the proportion of households with income below the poverty line. One of the government's efforts to control the rate of population growth is through the implementation of a family planning program (KB) for fertile age couples age (PUS) using contraception. The use of long term contraception methods is still very low, of the total number of active family planning participants, only $17.45 \%$ of them use long term contraception methods. Meanwhile, $81.23 \%$ were non- long term contraception methods family planning users and $1.32 \%$ used traditional family planning. Jambi Province only 1.9\% uses long term contraception method. Based on data obtained from the Jambi City Health Office in 2018 the number of IUD KB participants was 2,032, 1,252 implants, 542 MOW people, 16 MOP people from 20 community health center in Jambi City, Pakuan Baru community health center none of the active family planning participants which uses long term contraception method. This study was to determine the relationship of counseling by health workers with the choice of long-term contraceptive method at Pakuan Baru Community Health Center, Jambi City. This type of quantitative research with a descriptive design. Respondents who were active family planning participants who visited the Pakuan Baru community health center were taken using accidental sampling. The data collection technique was done by filling out a questionnaire. The data were processed using fisher exact statistical tests. The results of the study most of the respondents used long term contraception method of 24 (57.1\%), there was a relationship between the provision of counseling and the choice of long term contraception method with a p-value: 0.001 and there was no relationship between the provision of counseling media by health workers and the selection of long term contraception method with a p-value: 0.068 .
\end{abstract}

Keywords: family Planning, fertile age couple, long term contraception method

\begin{abstract}
Abstrak
Peningkatan jumlah penduduk dapat mengakibatkan kemiskinan, ketidakmerataan ekonomi pada populasi yang biasanya diukur dari proporsi rumah tangga dengan penghasilan di bawah garis kemiskinan. Salah satu upaya pemerintah untuk mengendalikan laju pertumbuhan penduduk adalah melalui pelaksanaan program keluarga berencana (KB) bagi pasangan usia subur (PUS) dengan pemakaian kontrasepsi. Penggunaan MKJP masih sangat rendah, dari keseluruhan jumlah peserta KB aktif, hanya 17,45\% diantaranya yang menggunakan KB MKJP. Sedangkan 81,23\% lainnya pengguna KB non MKJP dan 1,32\% menggunakan KB tradisional. Provinsi Jambi hanya 1,9\% menggunakan MKJP. Berdasarkan data yang diperoleh dari Dinas Kesehatan Kota Jambi tahun 2018 jumlah peserta KB AKDR sebanyak 2.032, implant sebanyak 1.252 orang, MOW sebanyak 542 orang, MOP sebanyak 16 orang dari 20 Puskesmas yang ada di Kota Jambi, Puskesmas Pakuan Baru tidak ada satupun peserta aktif KB yang menggunakan MKJP. Penelitian ini untuk mengetahui hubungan pemberian konseling oleh petugas kesehatan dengan pemilihan metode kontrasepsi jangka panjang (MKJP) di Puskesmas Pakuan Baru Kota Jambi. Jenis penelitian kuantitatif dengan desain deskriptif. Responden peserta KB aktif yang atang berkunjung ke
\end{abstract}


Puskesmas Pakuan Baru diambil menngunaka accidental sampling. Teknik pengumpulan data dilakukan dengan pengisian kuesioner. Data diolah menggunakan uji statistik fisher exact.

Hasil penelitian sebagian besar responden menggunakan MKJP sebesar 24 (57,1\%), terdapat hubungan antara pemberian konseling dengan pemilihan MKJP dengan $p$-value: 0,001 dan tidak terdapat hubungan antara pemberian media konseling oleh petugas kesehatan dengan pemilihan MKJP dengan nilai $p$-value: 0,068 .

Kata Kunci: keluarga berencana, MKPJ, pasangan usia subur

\section{PENDAHULUAN}

Program KB berkaitan erat dengan pertumbuhan penduduk di suatu negara. Indonesia mengalami persoalan besar yang sedang dialami oleh sebagian besar negaranegara di dunia yaitu masalah kependudukan. Laju pertumbuhan penduduk di Indonesia berada di posisi keempat dunia setelah China, India, Amerika Serikat. Berdasarkan survey penduduk tahun 2010 jumlah penduduk Indonesia sebesar 237,6 juta jiwa dengan tingkat laju pertumbuhan penduduk sekitar $1,49 \%$. Jika pemerintah tidak berhasil menekan angka pertumbuhan penduduk maka diprediksi jumlah penduduk Indonesia pada tahun 2060 mencapai 475 juta -500 juta (BKKBN, 2010).

Salah satu cara untuk mengendalikan laju pertumbuhan penduduk dengan program Keluarga Berencana (KB). KB merupakan tindakan yang membantu individu atau pasangan suami istri untuk mendapatkan objeltif tertentu, menghindari kelahiran yang tidak diinginkan, mengatur interval di antara kehamilan, mengontrol waktu saat kelahiran dalam hubungan suami istri dan menentukan jumlah anak dalam keluarga (WHO, 2009).

Program KB tidak hanya bertujuan untuk mengendalikan laju pertumbuhan penduduk, melainkan juga untuk memenuhi permintaan masyarakat akan pelayanan $\mathrm{KB}$ dan kesehatan reproduksi yang berkualitas, menurunkan angka kematian ibu (AKI) dan angka kematian bayi (AKB) serta penanggulangan masalah kesehatan reproduksi untuk membentuk keluarga kecil berkualitas (Kurniawati, 2013).
Alat kontrasepsi jangka panjang (MKJP) adalah alat kontrasepsi yang digunakan untuk menunda, menjarangkan kehamilan, serta menghentikan kesuburan, yang digunakan dengan jangka panjang, yang meliputi IUD, implant dan kontrasepsi mantap. Penggunaan MKJP masih sangat rendah, dari keseluruhan jumlah peserta $\mathrm{KB}$ aktif hanya $17,45 \%$ diantaranya yang menggunakan KB MKJP. Sedangkan 81,23 $\%$ lainnya pengguna $\mathrm{KB}$ non MKJP dan $1,32 \%$ menggunakan $\mathrm{KB}$ tradisional (Kemenkes, 2017). Realisasi pencapaian peserta KB baru MKJP dari 33 provinsi di Indonesia tertinggi terdapat pada provinsi Nusa Tenggara Timur sebanyak $10.0 \%$ dan Provinsi Jambi sebanyak 1,9\%.

Peserta KB aktif MKJP di Provinsi Jambi untuk pengguna metode IUD tertinggi terdapat di Kabupaten Kerinci sebesar 59,92 \% diikuti dengan Kota Jambi sebesar 52,13\%, metode implant terdapat pada Kabupaten Sarolangun sebesar $89.00 \%$ dan terendah di Kota Jambi sebesar $35.70 \%$, metode WOW tertinggi terdapat di Kota Jambi sebesar $11.06 \%$, dan metode MOP tertinggi terdapat di Kabupaten Tanjung Jabung Timur sebesar $8.78 \%$ (BKKBN, 2016)

Berdasarkan data yang diperoleh dari Dinas Kesehatan Kota Jambi tahun 2018 pada pemasangan MKJP jumlah peserta KB aktif metode kontrasepsi cara modern yaitu AKDR sebanyak 2.032, implant sebanyak 1.252 orang, MOW sebanyak 542 orang, MOP sebanyak 16 orang. Dari 20 Puskesmas yang ada di Kota Jambi, Puskesmas Pakuan Baru tidak ada peserta aktif KB yang menggunakan MKJP. 
Pelayanan program KB pelaksanaannya senantiasa terintegrasi dengan kegiatan kelangsungan hidup ibu, bayi dan anak serta penanggulangan masalah kesehatan dan kesetaraan gender sebagai salah satu upaya pemecahan hakhak reproduksi kepada masyarakat. Dalam mensosialisaikan kontrasepsi yang akan dipergunakan oleh akseptor $\mathrm{KB}$ sangat ditentukan efektvitas konseling petugas kesehatan (Saifuddin, 2014).

Faktor-faktor yang berhubungan dengan pemilihan MKJP pada wanita usia subur menurut hasil penelitian Niat Nuari (2017) adalah pengetahuan, sikap, persepsi tentang nilai anak, dukungan suami dan petugas kesehatan. Klien yang mendapatkan konseling dengan baik akan cenderung memilih alat kontrasepsi dengan benar dan tepat. Pada akhirnya hal itu juga akan menurunkan tingkat kegagalan $\mathrm{KB}$ dan mencegah terjadinya kehamilan yang tidak diinginkan. Untuk meraih keberhasilan tersebut, tentunya sangat diperlukan tenaga-tenaga konselor yang profesional. Mereka bukan hanya harus mengerti seluk-beluk masalah $\mathrm{KB}$, tetapi juga memiliki dedikasi tinggi pada tugasnya serta memiliki kepribadian yang baik, sabar, penuh pengertian, dan menghargai klien (Siswanto, 2010).

Hasil survei pendahuluan yang dilakukan di Puskesmas Pakuan Baru, menunjukkan faktor yang menyebabkan akseptor KB kurang memakai kontrasepsi jangka panjang antara lain adalah konseling petugas kesehatan yang kurang efektif antara tenaga kesehatan dengan akseptor $\mathrm{KB}$ tentang kontrasepsi jangka panjang. Konseling kepada akseptor KB di wilayah kerja Puskesmas Pakuan Baru sudah sering dilaksanakan oleh petugas kesehatan, namun konseling tersebut belum sesuai dengan yang diharapkan, hal ini dapat kita lihat bahwa akseptor KB masih lebih memilih metode non MKJP.
Berdasarkan uraian di atas peneliti merasa tertarik untuk melakukan penelitian dengan judul "hubungan pemberian konseling oleh petugas kesehatan terhadap pemilihan Metode Kontrasepsi Jangka Panjang (MKJP) di Puskesmas Pakuan Baru Kota Jambi”.

\section{METODE PENELITIAN}

Jenis penelitian ini adalah kuantitatif dengan desain deskriptif. Populasi dalam penelitian ini adalah seluruh peserta KB aktif di Puskesmas Pakuan Baru. Sampel dalam penelitian ini adalah Semua akseptor KB aktif yang datang berkunjung ke Puskesmas Pakuan Baru Kota Jambi yang diambil dengan menggunakan teknik accidental sampling. Instrumen pada penelitian ini menggunakan kuesioner yang diadopso dari penelitian Yusraini (2012). Kuesioner ini terdiri dari pertanyaan tentang materi dan media konseling yang digunakan oleh petugas kesehatan dalam memberikan konseling tentang MKJP. Analisis data menggunakan SPSS analisis univariat dan bivariat dengan uji statistik fisher exact untuk mengetahui hubungan konseling oleh petugas kesehatan dengan pemilihan MKJP

\section{HASIL DAN PEMBAHASAN \\ Gambaran Usia}

Berdasarakan hasil penelitian, didapatkan gambaran usia sebagai berikut :

\section{Tabel 1 Karakteristik Akseptor KB}

\begin{tabular}{llll}
\hline karakteristik & parameter & $\begin{array}{c}\text { Frekue } \\
\text { nsi }\end{array}$ & $\begin{array}{l}\text { Persenta } \\
\text { se (\%) }\end{array}$ \\
\hline Umur (th) & Berisko & 11 & 26.2 \\
& Tidak bersiko & 31 & 73.8 \\
pendidikan & Dasar & 2 & 4.8 \\
& Menengah & 33 & 78.5 \\
& Tinggi & 7 & 16.6 \\
Pekerjaan & Tidak bekerja & 37 & 88.1 \\
& Bekerja & 5 & 11.9 \\
paritas & Grandemultipara & 2 & 4.8 \\
& Multipara & 33 & 78.6 \\
Total & primipara & 7 & 16.7 \\
& & 42 & 100.0 \\
\hline
\end{tabular}


Usia responden sebagian besar berada pada usia tidak beresiko sebanyak 31 responden $(73.8 \%)$, sebagian besar responden tidak bekerja sebanyak 37 responden $(88.1 \%)$, sebagian besar paritas responden mempunyai anak lebih dari satu orang sebanyak 33 responden $(78.6 \%)$

Umur merupakan faktor instrinsik seseorang dalam pengambilan keputusan, termasuk dalam menentukan keputusan menggunakan alat konstrasepsi. Umur 2035 tahun merupakan umur yang tidak berisiko karena masa ini merupakan masa dimana organ, fungsi reproduksi dan sistim hormonal seorang wanita cukup matang untuk mempunyai anak (Dewi dan Notobroto, 2014). Semakin tua seseorang maka alat pemilihan kontrasepsi ke arah alat yang empunyai efektifitas lebih tinggi yakni MKJP (BKKBN, 2013). Sejalan dengan penelitian Aningsih, B \& Irawan, Y (2019) bahwa terdapat hubungan antara umur dan penggunaan MKJP dengan nilai $\mathrm{p}=0,029$.

Pendidikan merupakan salah satu faktor yang mempengaruhi seseorang dalam menerima ide baru, termasuk kontrasepsi. Menurut Notoatmodjo (2007) Pendidikan merupakan salah satu faktor yang mempengaruhi pengetahuan orang atau keluarga dalam masyarakat. pendidikan merupakan proses perubahan sikap dan tata laku seseorang atau kelompok orang dalam usaha mendewasakan manusia melalui upaya pengajaran dan pelatihan. Semakin tinggi tingkat pendidikan seseorang, maka makin mudah dalam memperoleh menerima informasi, sehingga kemampuan ibu dalam berpikir lebih rasional. Hal ini sejalan dengan penelitian Aningsih, B \& Irawan, Y (2019) bahwa terdapat hubungan antara tingkat pendidikan dan penggunaan MKJP dengan nilai $\mathrm{p}=0,005$.

Pekerjaan akan memperluas pengetahuan seseorang, sehingga banyak mendapatkan informasi untuk mempermudah seseorang dalam menentukan kontrasepsi yang efektif. Menurut penelitian Aningsih, B \& Irawan, Y (2019) bahwa tidak terdapat hubungan antara pekerjaan dan penggunaan MKJP dengan nilai $\mathrm{p}=0,443$.

Jumlah anak hidup yang dimiliki oleh seorang wanita mempengaruhi dalam pemilihan alat kontrasepsi yang akan digunakan. Keputusan untuk memiliki sejumlah anak adalah sebuah pilihan, yang mana pilihan tersebut sangat dipengaruhi oleh nilai yang dianggap sebagai satu harapan atas keinginan yang dipilih oleh orangtua (Kusumaningrum, 2009). Hal ini sejalan dengan hasil penelitian Aningsih, B \& Irawan, Y (2019) bahwa terdapat hubungan antara paritas dan penggunaan MKJP dengan nilai $\mathrm{p}=0,023$.

\section{Hubungan Pemberian Konseling oleh Petugas Kesehatan terhadap Pemilihan MKJP}

Berdasarkan hasil penelitian didapatkan Hubungan Pemberian Konseling oleh Petugas Kesehatan terhadap Pemilihan MKJP sebgai berikut:

Tabel 2. Hubungan pemberian konseling oleh petugas kesehatan terhadap pemilihan MKJP

\begin{tabular}{|c|c|c|c|c|c|c|c|c|}
\hline \multirow{2}{*}{\multicolumn{2}{|c|}{$\begin{array}{l}\text { Pemberian konseling } \\
\text { petugas kesehatan }\end{array}$}} & \multicolumn{4}{|c|}{ Pemilihan MKJP } & & & \\
\hline & & \multicolumn{2}{|c|}{ Non MKJP } & \multicolumn{2}{|c|}{ MKJP } & \multicolumn{2}{|c|}{ Total } & \multirow[t]{2}{*}{ p-value } \\
\hline & & $\mathbf{n}$ & $\%$ & $\mathbf{n}$ & $\%$ & $\mathbf{N}$ & $\%$ & \\
\hline \multirow[t]{3}{*}{ Materi Konseling } & Tidak & 7 & 38.9 & 11 & 61.1 & 18 & 100 & \multirow{3}{*}{0.001} \\
\hline & Efektif & & & & & & & \\
\hline & Efektif & 0 & 0 & 24 & 100 & 24 & 100 & \\
\hline \multirow[t]{2}{*}{ Media Konseling } & Tidak & 5 & 21.8 & 13 & 56.5 & 23 & 100 & \multirow{2}{*}{0.068} \\
\hline & efektif & 1 & 4.17 & 23 & 95.9 & 24 & 100 & \\
\hline
\end{tabular}


Berdasarkan tabel 2 hasil analisis terdapat hubungan signifikan pemberian materi konseling dengan pemilihanMKJP dengan nilai $p$-valueI: 0,001 . Tidak terdapat hubungan signifikan antara media konseling dengan pemilihan MKJP dengan nilai $p$-value: 0,068 .

Materi konseling yang diterima oleh akseptor $\mathrm{KB}$ akan berpengaruh terhadap pengetahuan ibu, dengan materi yang efektif yang diperolehnya, akan berusaha untuk lebih mengetahui tentang kontrasepsi jangka panjang dan lebih berupaya mencari informasi tentang jenis dan manfaat jenis kontrasepsi. Materi akan membuat seseorang ingin lebih mengetahui lebih banyak hal yang diperlukan dan lebih tanggap terhadap informasi serta peka melihat perubahan-perubahan yang terjadi (Santosa, H, 2012).

Terdapat kesamaan pada hasil penelitian Mulianda, $\mathrm{R}$ dan Gultom, D (2019) yang menunjukkan ada hubungan antara pemberian materi konseling oleh petugas kesehatan dengan pemilihan MKJP. Hasil penelitian Santoso, H (2012) menunjukkan bahwa semakin efektif materi penyuluhan konseling petugas kesehatan kepada akseptor KB makan akan meningkatkan pengetahuan ibu tentang kontrasepsi jangka panjang.

Hasil konseling menurut McLeod (2006) dimana setelah mengikuti konseling memungkinkan seseorang untuk mendapatkan pemahaman, keterampilan, dan strategi baru yang membuat diri klien bisa menangani masalah serupa dengan lebih baik dimasa yang akan datang. Materi konseling dibuat untuk memenuhi kebutuhan dan kepentingan ibu dengan memperhatikan topik yang sesuai dengan kontrasepsi jangka panjang. Konseling yang diberikan oleh petugas kesehatan efektif dalam pemilihan MKJP di Puskesmas Pakuan Baru.
Media konseling penting karena merupakan dasar alat yang dipergunakan untuk menyampaikan pesan atau informasi agar dapat diterima dengan mudah oleh orang-orang. Namun, tidak hanya media yang mempengaruhi keberhasilan konseling. Materi yang baik dan metode yang tepat juga dapat mempengaruhi keberhasilan konseling. Petugas kesehatan di Puskesmas Pakuan Baru memberikan konseling $\mathrm{KB}$ menggunakan alat bantu pengambil keputusan (ABPK) ber $\mathrm{KB}$, poster dan leaflet.

Terdapat perbedaan dengan hasil Mulianda, R dan Gultom, D (2019) yang menunjukkan ada hubungan antara pemberian media konseling oleh petugas kesehatan dengan pemilihan MKJP. Hasil penelitian Santoso, H (2012) menunjukkan bahwa semakin efektif media penyuluhan konseling petugas kesehatan kepada akseptor KB maka akan meningkatkan pengetahuan ibu tentang kontrasepsi jangka panjang.

Faktor lain yang menjadi keberhasilan dalam proses konseling adalah konselor mampu menumbuhkan kepercayaan dan motivasi ibu, sehingga ibu bisa menerima konselor sebagai sumber informasi yang berdampak terhadap keberanian ibu dalam mengungkapkan ketidaktahuan yang dihadapi sebelumnya.

\section{SIMPULAN}

Sebagian besar responden menggunakan MKJP sebesar 24 (57,1\%), terdapat hubungan antara pemberian konseling dengan pemilihan MKJP dengan $p$-value: 0,001 dan tidak terdapat hubungan antara pemberian media konseling oleh petugas kesehatan dengan pemilihan MKJP dengan nilai p-value: 0,068.

\section{SARAN}

Perlu diadakan penelitian lebih lanjut dengan variabel yang berbeda yang berkaitan dengan MKJP, seperti melihat 
perbedaan pengaruh konseling dan Mulianda, R \& Gultom, D. 2019. Pengaruh penyuluhan terhadap pemilihan MKJP

DAFTAR PUSTAKA

Aningsih, B, Irawan, Y. 2019. Hubungan Umur, Tingkat Pendidikan, Pekerjaan dan Paritas terhadap Penggunaan Metode Kontrasepsi Jangka Panjang (MKJP) di Dusun III Desa Pananjung Kecamatan Cangkuang Kabupaten Bandunf. Jurnal Kebidanan 8 (1).

BKBN. 2013. Profil Kependudukan dan Pembangunan di Indonesia Tahun 2013. Badan Kependudukan dan Keluarga Berencana Nasional Jakarta..

BKKBN. 2010. Keluarga Berencana dan Kesehatan Reproduksi. Jakarta : BKKBN, 2010.

BKKBN. 2016. Pelayanan Kontrasepsi. Jakarta : BKKBN, 2016.

Dewi, P HC dan Notroboto, HB. 2014. rendahnya Keikutsertaan Pengguna Metode Kontrasepsi Jangka Panjang pada Pasangan Usia Subur. Jurnal Biometrika dan Kependudukan, Vol.3, No. 1.

Kemenkes, RI. 2017. Profil Kesehatan Indonesia Tahun 2017. Jakarta : Kemenkes RI, 2017.

Kurniawati, Yuhedi T.L dan. 2013. Buku Ajar Kependudukan dan Pelayanan KB. Jakarta : EGC, 2013.

Kusumaningrum, R. 2009. Faktor-faktor yang Mepengaruhi Pemilihan Jenis Kontrasepsi yang digunakan pad Pasangan Usia Subur. Skripsi. Semarang: Universitas Diponegoro: 34-35.
Pemberian Konseling KB terhadap

Pemilihan Kontrasepsi Jangka Panjang (MKJP) di Kelurahan Belawan Bahagia. Jurnal Ilmiah Kebidanan Imelda. Vol 5 (2).

Saifuddin, Abdul Bari. 2014. Buku Panduan Praktis Pelayanan Kesehatan Maternal dan neonatal. YBP-SP. Jakarta.

Santoso, Heru. 2012. Pengaruh Pemberian Konseling Oleh Petugas Kesehatan terhadap Pengetahuan Ibu dalam Pemilihan Alat Kontrasepsi Jangka Panjang di Wilayah Kerja Puskesmas Desalama Kabupaten Langkat. Universitas Sumatera Utara.

Yusraini. 2012. Pengaruh Pemberian Konseling oleh Petugas Kesehatan terhadap Pengetahuan Ibu tentang Pemilihan Alat Kontrasepsi Jangka Panjang di Wilayah Kerja Puskesmas Desa Lama Kabupaten Langka, Tesis, Fakultas Kesehatan Masyarakat, Universitas Sumatera Utara

Zebua, Niat Nuari. 2017. Faktor-faktor yang Berhubungan dengan Pemilihan Metode Kontrasepsi Jangka Panjang pada Wanita Usia Subur di Desa Tebing Tinggi Kecamatan Tanjung Beringin Serdang Bedagai tahun 2017. Jurnal Kesehatan Masyarakat. http://repositori.usu.ac.id/handle/12345 6789/2179 